\title{
Available Heavy Metal Concentrations and their Influencing Factors in Cropland and Fallows of Different Age in Tropical Area
}

\author{
Zeyang Zhao, Zhizhong Zhao*, Bo Fu, Dan Wu, Junguang Wang, Wei Tang \\ College of Geography and Environmental Science, Hainan Normal University, Haikou, Hainan, China
}

Received: 28 February 2020

Accepted: 13 August 2020

\begin{abstract}
To explore the effects of soil properties affected by fallow ages on available heavy metal concentrations in tropical China areas, a total of 144 topsoil samples were investigated from croplands and fallows. The total and available concentrations of chromium $(\mathrm{Cr})$, copper $(\mathrm{Cu})$, zinc $(\mathrm{Zn})$, and lead $(\mathrm{Pb})$ in the soil samples were analysed. Soil characteristics (total concentrations, $\mathrm{pH}$, redox potential (Eh), organic matter (OM), particulate diameter) that may affect the available heavy metals were investigated. Additionally, the relationship between soil characteristics and available heavy metals was analysed. The results showed that the $\mathrm{pH}$ was lower and the $\mathrm{Eh}$ and $\mathrm{OM}$ were higher in cropland with frequent cultivation when compared to fallows which were disturbed rarely by anthropogenic activities. The particulate diameter of cropland was relatively small. The concentrations of total and available heavy metals first increased and then decreased as fallows aged. The available $\mathrm{Cr}$ is mainly affected by its total concentration, while the concentrations of available $\mathrm{Cu}, \mathrm{Zn}$ and $\mathrm{Pb}$ are affected by the physicochemical properties. Soil properties of fallows changed, and the concentrations of available heavy metals can be reduced, which can reduce the bioavailability, biological toxicity and environmental impact.
\end{abstract}

Keywords: potentially toxic elements, fallow duration, physicochemical properties, agricultural soil

\section{Introduction}

Soil is an important component of the terrestrial ecosystem and for human survival and sustainable development. Soil is not only the destination of heavy metals but also the source of heavy metals to the atmosphere, water and organisms [1-3]. Heavy metals in soil cannot be degraded by microorganisms; they are highly toxic, easily accumulate and can even be

*e-mail: hnenvironment@163.com converted into more toxic compounds [4]. Most heavy metals which include $\mathrm{Cr}, \mathrm{Pb}, \mathrm{Zn}$ and $\mathrm{Cu}$ not only reduce the fertility of soil, affect root growth and reduce crop productivity but also harm human health through their transfer up when introduced in the food chain, especially when they are available in dissolved form [5-6]. Many studies have shown that the migration and transformation of heavy metals in soils and their impact on the environment are related not only to their total concentration but also to their available concentration [7-9]. The bioavailable fraction is the total amount of a chemical present in a specific environmental compartment that, within a given time span, is either 
available or can be made available for uptake by (micro)organisms from either the direct surroundings of the organism or by ingestion of food [10]. The available concentration of heavy metals is restricted by many factors in soil [11]. For example, the available concentration of heavy metals increases inversely with $\mathrm{pH}$ and decreases inversely with redox potential (Eh) and organic matter (OM) [12-13]. By exploring available heavy metal concentrations in soil and their potential migration and transformation in soil, their potential risk to the ecological environment can be better evaluated. Such studies can also provide a scientific and effective basis for the remediation of heavy metal pollution in soil.

In recent years, the contamination of heavy metals in soils has attracted much attention by scholars. A large number of studies on heavy metals in soil have been carried out with respect to source analysis, risk assessment, remediation, spatial distribution and variability [14-17]. Fallowing is allowing land to lie undisturbed for a season or more for fertility restoration. Improved fallow had been proposed as a solution to the heavy metal pollution associated with fertilizer application [18]. However, research on particular topics should be further studied, for example, whether the concentrations of available heavy metals can be reduced as fallows aged, the effect of the fallow duration on available heavy metal concentrations, and how long is the most suitable fallow duration. Because of the more favourable cultivation conditions in tropical areas and more times of cultivation in a year, more fertilizers and pesticides are applied, which leads to the accumulation of heavy metals. In addition, the high temperature and precipitation in tropical areas will affect the concentration of available heavy metals during the fallow period. As the largest tropical island in southern China, Hainan Province has a unique geographical location and climate, more favourable production conditions, a large proportion of agricultural land, a high utilization rate, a high anthropogenic disturbance, and a variety of land-use types. This research aimed to address the following objectives: 1) to evaluate the effect of fallow ages on the dynamics of the total and available concentrations of four heavy metals $(\mathrm{Cr}, \mathrm{Cu}, \mathrm{Zn}, \mathrm{Pb})$ in surface $(0-30 \mathrm{~cm})$ soil layer from croplands and fallows (laid fallow for 1-3 years, $3-5$ years and $>5$ years); 2) to determine the relationships between available heavy metal concentrations and soil characteristics (total concentrations, $\mathrm{pH}$, Eh, OM, particulate diameter). An attempt was made to provide a theoretical basis for protecting the environment of agricultural land, ensuring the safety of agricultural production and preventing soil pollution.

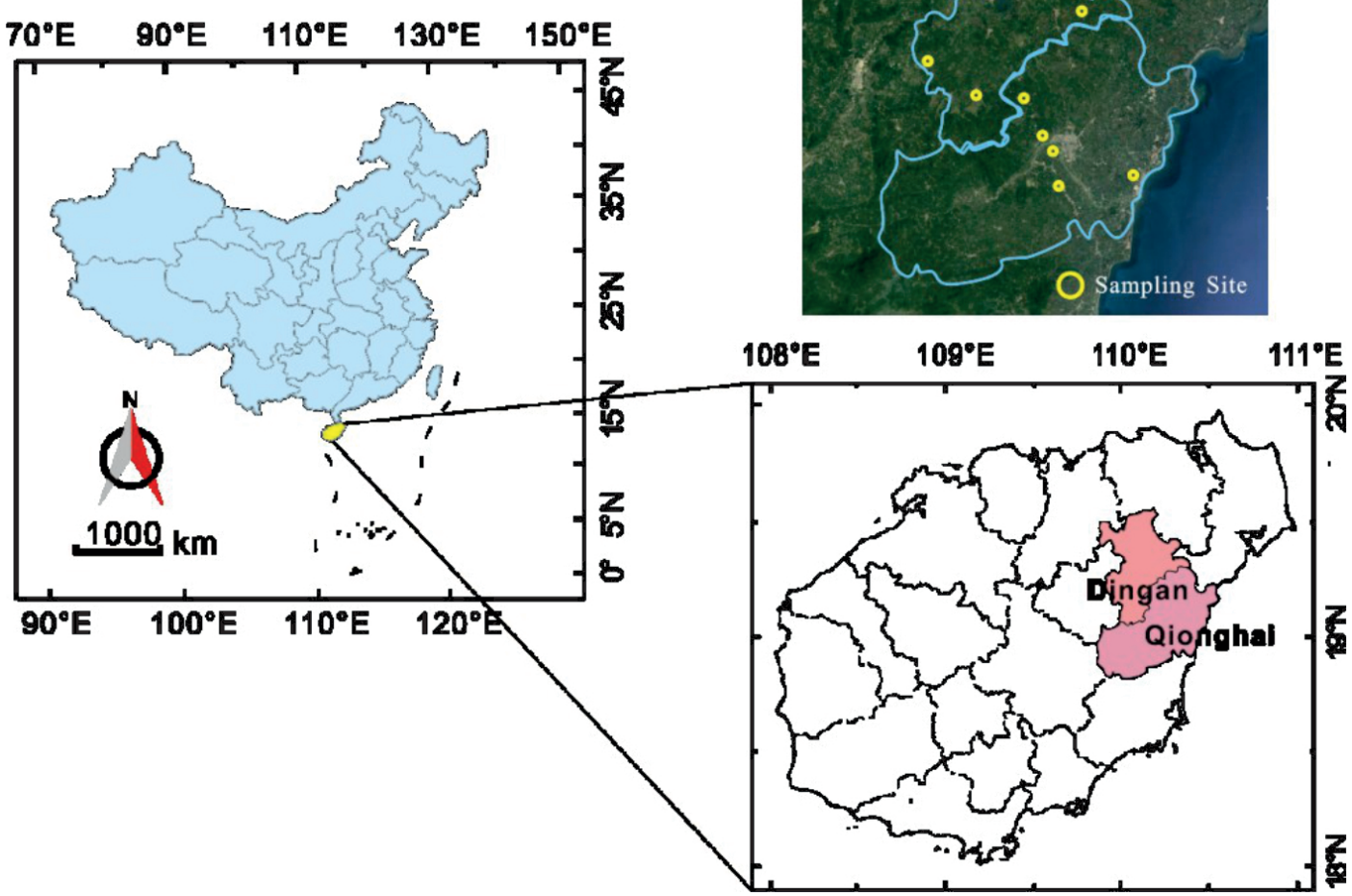

Fig. 1. The location of the study area and distribution of the sampling sites. 


\section{Materials and Methods}

\section{Study Area}

The study area $\left(18^{\circ} 58^{\prime}-19^{\circ} 44^{\prime} \mathrm{N}, 110^{\circ} 07^{\prime}-110^{\circ} 40^{\prime} \mathrm{E}\right)$ is located in eastern Hainan Province, China, and includes Qionghai and Dingan counties. The total area is approximately $2899 \mathrm{~km}^{2}$, and the cultivated area is $452.59 \mathrm{~km}^{2}$, accounting for $15.6 \%$ of the total area. The study area is classified as a tropical monsoon climate zone that is greatly affected by monsoons, with high annual precipitation and frequent typhoons. The study area has an annual temperature of $24^{\circ} \mathrm{C}$ and an annual average precipitation of $1997 \mathrm{~mm}$, with an uneven temporal distribution where most of the precipitation falls between May and October [19]. The rocks in the area are mainly basalt, magmatic rock and granite. The topography is high in the southwest and low in the northeast. The landform mainly consists of platform, terrace and plain areas.

Lateritic soil is the main representative soil type (GB/T 17296-2009). The parent materials of the soil are complex. Yellow latosol has fine and uniform sand grains. Ferruginous laterite has a deep layer and a high OM content. The main landscapes of the cultivated area are paddy fields, dryland, orchards, and woodlands. Early indica rice and late indica rice are grown in the paddy fields. Peanuts, root and tuber crops, Luffa, and cowpea are grown under dryland conditions.

\section{Sample Sources and Pretreatment}

Based on the understanding of the spatial distribution of agricultural land in the study area, twelve sampling sites with more favourable agricultural production conditions, complex land-use types and management measures were selected according to the principles of typicality and representativeness, as illustrated in Fig. 1. At each sampling site, one cropland and three fallows (laid fallow for 1-3 years, 3-5 years and $>5$ years, respectively) were selected as sample plots. In croplands, rice has been cultivated for more than 5 years, and the planting method is based on crop rotation. In fallows, rice, peanuts and other crops were planted before croplands laid fallow. Each sample plot was adjacent and approximately $20 \mathrm{~m} \times 20 \mathrm{~m}$. A total of 48 sample plots were selected. To improve the representativeness of the samples, each soil sample consisted of 5 subsamples collected in a $5 \mathrm{~m} \times 5 \mathrm{~m}$ grid from the sampling plot at depths of 0-10, 10-20 and $20-30 \mathrm{~cm}$. A total of $1 \mathrm{~kg}$ of fresh soil was collected from the mixed samples using a quartile method. A total of 144 samples were collected during soil sampling. At the same time, we recorded the cultivation and fertilization history of the sampled land areas in recent years through interviews with farmers. The collected soil samples were stored in polyethylene bags for transport to the laboratory.
The samples were placed in plastic trays. Impurities, such as plant roots and gravel, were removed. Then, clods were air-dried $\left(20-25^{\circ} \mathrm{C}\right)$, crushed into small particles with a wooden hammer and sieved through a $0.15-\mathrm{mm}$ sieve. These samples were used for soil physicochemical property and elemental analyses.

\section{Analytical Methods}

Soil samples in croplands and fallows of different age were analysed directly after acid microwave digestion (Milestone, Italy). Guaranteed reagentgrade chemicals and ultra-pure water were used for all procedures, unless stated otherwise. The concentrations of heavy metals were measured using inductively coupled plasma-mass spectrometry (ICP-MS, Agilent 7900, Agilent Technologies, Santa Clara, CA, USA). For total heavy metal analysis, the solids were digested with a mixture of hydrofluoric and nitric acids. Soil samples ( $0.1 \mathrm{~g}$ dry weight) were digested in a pre-cleaned Teflon digestion tank with a solution of concentrated nitric acid $\left(\mathrm{HNO}_{3} ; 6 \mathrm{~mL}\right)$ and hydrofluoric acid (HF; $\left.3 \mathrm{~mL}\right)$. The samples were subjected to acid microwave digestion for 20 min after heating up to $200{ }^{\circ} \mathrm{C}$. After digestion and cooling, the digest solution was placed on a hot plate, heated at $120^{\circ} \mathrm{C}$ to near dryness with $0.5 \mathrm{~mL}$ of $\mathrm{H}_{2} \mathrm{O}_{2}$, and washed and dissolved with $0.02 \mathrm{~mol}$ of $\mathrm{HNO}_{3}$ after cooling. Each sample was quantitatively transferred to a volumetric flask, which was then filled to $50 \mathrm{~mL}$ with ultrapure water.

An environmental mixed calibration standard of $\mathrm{Cr}, \mathrm{Cu}, \mathrm{Pb}, \mathrm{Zn}$ and $\mathrm{Cd}(10 \mu \mathrm{g} / \mathrm{mL}$, Agilent, Part\# 51834688) was diluted to produce a standard solution series in stages with 5\% nitric acid (Merck, Germany). A mixed internal standard stock solution of ${ }^{6} \mathrm{Li},{ }^{45} \mathrm{Sc},{ }^{72} \mathrm{Ge}$, ${ }^{89} \mathrm{Y},{ }^{115} \mathrm{In},{ }^{159} \mathrm{~Tb}$, and ${ }^{209} \mathrm{Bi}(10 \mu \mathrm{g} / \mathrm{mL}$, Agilent, part\# 5183-4680) was diluted to $1 \mu \mathrm{g} / \mathrm{mL}$ with $5 \%$ nitric acid (Merck, Germany). Under optimum conditions, blank and standard solution series were measured, and the standardization curves were automatically drawn by the instrument $(r \geq 0.9999)$. The main operating parameters of the instrument were as follows: RF power $1550 \mathrm{~W}$, cooling gas $15.0 \mathrm{~L} / \mathrm{min}$, auxiliary gas $1.0 \mathrm{~L} / \mathrm{min}$, carrier gas $1.06 \mathrm{~L} / \mathrm{min}$, oxide formation $(\mathrm{CeO} / \mathrm{Ce}<0.5 \%)$, and doubly charged $\left(\mathrm{Ce}^{2+} / \mathrm{Ce}^{+}<2 \%\right)$. The isotopes used were ${ }^{53} \mathrm{Cr},{ }^{66} \mathrm{Zn},{ }^{63} \mathrm{Cu},{ }^{114} \mathrm{Cd}$, and ${ }^{208} \mathrm{~Pb}$. The recoveries were between $85 \%$ and $125 \%$, and the relative standard deviation was less than $5 \%$. The heavy metal concentrations of each sample and blank samples were analysed.

A single step extraction procedure, based upon diethylenetriaminepentaacetic (DTPA) extraction, has been utilized in this study [20]. The DTPA extraction solution consisted of $0.005 \mathrm{~mol} / \mathrm{L}$ DTPA with $0.01 \mathrm{~mol} / \mathrm{L} \mathrm{CaCl}_{2}$ and $0.1 \mathrm{~mol} / \mathrm{L}$ triethanolamine at $\mathrm{pH}$ of 7.3. A mass ratio of 1:10 soil: DTPA solution was shaken for $2 \mathrm{~h}$, and then the suspension was centrifuged at $4000 \mathrm{rpm}$ for $20 \mathrm{~min}$, filtered through a $0.2 \mu \mathrm{m}$ 
porosity cellulose nitrate filter [21]. Extracts were analysed using an ICP-MS to determine the available concentrations of $\mathrm{Cr}, \mathrm{Cu}, \mathrm{Zn}$ and $\mathrm{Pb}$ in the soil.

Soil $\mathrm{pH}$ and $\mathrm{Eh}$ were determined in a 1:5 (soil:water ratio, w/v) suspension with a $\mathrm{pH}$ meter [22]. Soil organic carbon was first measured by wet oxidation, and the values were then converted to soil OM using the transfer factor of 1.724 [23]. Soil particulate diameter was determined with a particle size analyser (Mastersizer2000, Malvern, UK) [24].

The statistical differences of selected soil physicochemical properties and heavy metal distributions were determined by one-way analysis of variance (ANOVA) and were tested by homogeneity of variance test. The test of least significant difference ( $\mathrm{LSD}<5 \%$ ) was used to form homogeneous groups and differentiate between treatments. Correlations between distributions of available heavy metal and total heavy metal and selected soil properties were tested using Pearson's correlation test. All statistical analyses in this study were performed with SPSS 19.0 and Excel 2010 software. Figures were drawn using Origin 2017 and CorelDRAW X4 software.

\section{Results and Discussion}

\section{Soil Physicochemical Characterizations}

The selected soil physicochemical properties in cropland and fallows of different age are summarized in Table 1. The results showed that there were significant differences in $\mathrm{pH}$, Eh and $\mathrm{OM}$ between cropland and fallows of different age $(\mathrm{P}<0.05)$, while there were no significant differences in D10, D50 and D90. The soil in the study area was slightly acidic with a $\mathrm{pH}$ ranging from 5.14 to 7.29 . The average values of soil $\mathrm{pH}$ were 5.68, 5.86, 5.99 and 6.61 in cropland, 1-3 year fallow, 3-5 year fallow and >5-year fallow, respectively. The Eh of cropland and fallows of different age were $73.00-129.40,81.30-92.60,71.30-89.10$ and 2.20-52.70 mV, respectively. The Eh of $>5$-year fallow was significantly lower than that of cropland, 1-3 year fallow and 3-5 year fallow, which indicated that the soil of $>5$-year fallow was weakly oxidizable. Soil OM decreased as fallows aged, which was contrary to $\mathrm{pH}$. Overall, the particulate diameter of 1-3 year fallow was larger than that of cropland soil, 3-5 year fallow and >5-year fallow. The coefficient of variation of soil physicochemical properties is $1.34-134.90 \%$. The variation of particulate diameter and $\mathrm{OM}$ is relatively large, and the variation of $\mathrm{pH}$ and $\mathrm{Eh}$ is relatively small, which indicates that the former is more likely to be affected when external conditions change. Soil physical and chemical characteristics along with microbial properties will change with different duration of fallow, and will further affect the migration and distribution of available heavy metals in soil.

Driven by economic benefits, farmers applied a large number of pesticides and fertilizers to increase crop yields, which led to the acidification of cropland and the decrease of $\mathrm{pH}$. Rice is planted in croplands of the sampling site. The soil microenvironment is relatively humid, and the base cations are easily leached. As a result, $\mathrm{H}^{+}$accumulates on the soil colloid, and the soil $\mathrm{pH}$ is low. Usually, Eh is negatively correlated with $\mathrm{pH}$, and the Eh in cropland is higher than that in fallows, which is contrary to $\mathrm{pH}$. The $\mathrm{OM}$ in cropland was higher than that in fallows. Anthropogenic activities such as the application of organic fertilizers make OM continuously supplemented in cropland, which is conducive to the accumulation of OM. Because of long-term tillage, the coarse particles were fragmented, and the particulate diameter of cropland was relatively small. Compared with 3-5 year fallow and >5-year fallow, the particulate diameter of 1-3 year fallow was large. Because of the low vegetation coverage in 1-3 year fallow, the fine particles of soil tend to migrate downward with precipitation and easily lose with surface runoff.

Table 1. Selected soil physicochemical properties in cropland and fallows of different age.

\begin{tabular}{|c|c|c|c|c|c|c|c|}
\hline Soil type & Item & $\mathrm{pH}$ & $\mathrm{Eh}(\mathrm{mV})$ & $\mathrm{OM}(\mathrm{g} / \mathrm{kg})$ & $\mathrm{D} 10(\mu \mathrm{m})$ & $\mathrm{D} 50(\mu \mathrm{m})$ & $\mathrm{D} 90(\mu \mathrm{m})$ \\
\hline \multirow{3}{*}{ Cropland } & Mean & $5.68^{\mathrm{c}}$ & $97.57^{\mathrm{a}}$ & $31.44^{\mathrm{ab}}$ & $4.71^{\mathrm{a}}$ & $39.47^{\mathrm{a}}$ & $159.84^{\mathrm{a}}$ \\
\cline { 2 - 8 } & S.E. & 0.08 & 4.88 & 4.32 & 0.58 & 7.04 & 25.44 \\
\hline \multirow{3}{*}{ Fallow (1-3 years) } & Mean & $5.86^{\mathrm{b}}$ & $86.44^{\mathrm{ab}}$ & $19.56^{\mathrm{b}}$ & $10.08^{\mathrm{a}}$ & $80.50^{\mathrm{a}}$ & $244.60^{\mathrm{a}}$ \\
\cline { 2 - 9 } & S.E. & 0.03 & 1.58 & 2.38 & 3.70 & 28.17 & 59.95 \\
\hline \multirow{2}{*}{ Fallow (3-5 years) } & Mean & $5.99^{\mathrm{b}}$ & $79.08^{\mathrm{b}}$ & $18.69^{\mathrm{b}}$ & $3.00^{\mathrm{a}}$ & $28.27^{\mathrm{a}}$ & $116.48^{\mathrm{a}}$ \\
\cline { 2 - 9 } & S.E. & 0.04 & 2.46 & 3.99 & 0.39 & 2.07 & 12.66 \\
\hline \multirow{2}{*}{ Fallow (>5 years) } & Mean & $6.61^{\mathrm{ab}}$ & $35.71^{\mathrm{c}}$ & $12.73^{\mathrm{b}}$ & $4.83^{\mathrm{a}}$ & $38.98^{\mathrm{a}}$ & $179.18^{\mathrm{a}}$ \\
\cline { 2 - 9 } & S.E. & 0.19 & 7.41 & 2.09 & 2.66 & 15.63 & 48.03 \\
\hline
\end{tabular}

$\mathrm{Eh}=$ redox potential; $\mathrm{OM}=$ organic matter; D10, D50, D $90=10^{\text {th }}-50^{\text {th }}-90^{\text {th }}$ percentile of particle diameter curve;

S.E. $=$ Standard error. Within individual depths, mean values with different letters are significantly different, and those with similar letters are non-significant (LSD, $\mathrm{p}<0.05$ ). 
Total and Available Concentrations of Heavy Metals in Cropland and Fallows of Different Age

The total and available concentrations of $\mathrm{Cr}$, $\mathrm{Cu}, \mathrm{Zn}$ and $\mathrm{Pb}$ in cropland and fallows of different age were analysed. The results are shown in Fig. 2. The total concentrations of $\mathrm{Cr}, \mathrm{Cu}, \mathrm{Zn}$ and $\mathrm{Pb}$ in soils were $31.06-55.60,26.67-47.18,10.47-25.12$ and $9.22-13.18 \mathrm{mg} / \mathrm{kg}$, respectively, showing a trend of $\mathrm{Cr}>\mathrm{Cu}>\mathrm{Zn}>\mathrm{Pb}$. The concentration of $\mathrm{Cr}$ is the highest in soil laid fallow for 3-5 years and that of $\mathrm{Cu}, \mathrm{Zn}$ and $\mathrm{Pb}$ is the highest in soil laid fallow for 1-3 years. It can be seen that the total concentration of heavy metals in short-term fallow soil was even higher than that in cropland soil, but the total concentration of heavy metals gradually decreased as fallows aged. The average concentrations of available $\mathrm{Cr}, \mathrm{Cu}, \mathrm{Zn}$ and $\mathrm{Pb}$ were $8.34,17.20,4.92$ and $4.57 \mathrm{mg} / \mathrm{kg}$, respectively, showing a trend of $\mathrm{Cu}>\mathrm{Cr}>\mathrm{Zn}>\mathrm{Pb}$. Among different duration of fallow, the trend of available and total heavy metals showed a notable consistency, indicating that long-term fallow can reduce the concentration of heavy metals.

Most types of pesticides and fertilizers used in agricultural production contain heavy metals [25]. Therefore, pesticides and fertilizers have become an important source of heavy metals to cropland. Studies have shown that fallow ages can affect the distribution of heavy metal concentrations, and long-term fallow of the soil can reduce the concentration of heavy metals
[26]. In this study, the total and available concentrations of $\mathrm{Cu}, \mathrm{Zn}$ and $\mathrm{Pb}$ gradually decreased in soils that has been laid fallow for more than 3 years, while the total and available concentrations of $\mathrm{Cr}$ in soils gradually decreased in soils that had been laid fallow for more than 5 years, which was consistent with Tang et al. [27]. However, the concentration of heavy metals in 1-3 year fallow soils is higher than that in cropland. In the study area, fallow is adjacent to cropland. Typhoons and rainstorms occur frequently. Run-off in the cropland often flows into fallow across ridges, resulting in the fallow receiving heavy metals as well. The fallow has not been managed for a long time, so the soil is compacted, and heavy metals are accumulating continuously. Because of long-term tillage, the cropland soil is relatively loose, which is conducive to the migration of heavy metals to lower soil layers. In addition, crops also absorb some of the heavy metals in soil, resulting in heavy metals in cropland soil being lower than those in 1-3 year fallow soil.

\section{Factors Influencing Available Concentrations of Heavy Metals}

\section{Total Concentrations of Heavy Metals}

Different soil components can transform heavy metals into various fractions after entering the soil. Different environmental media can make heavy metals have a different bioavailability and mobility, reflecting

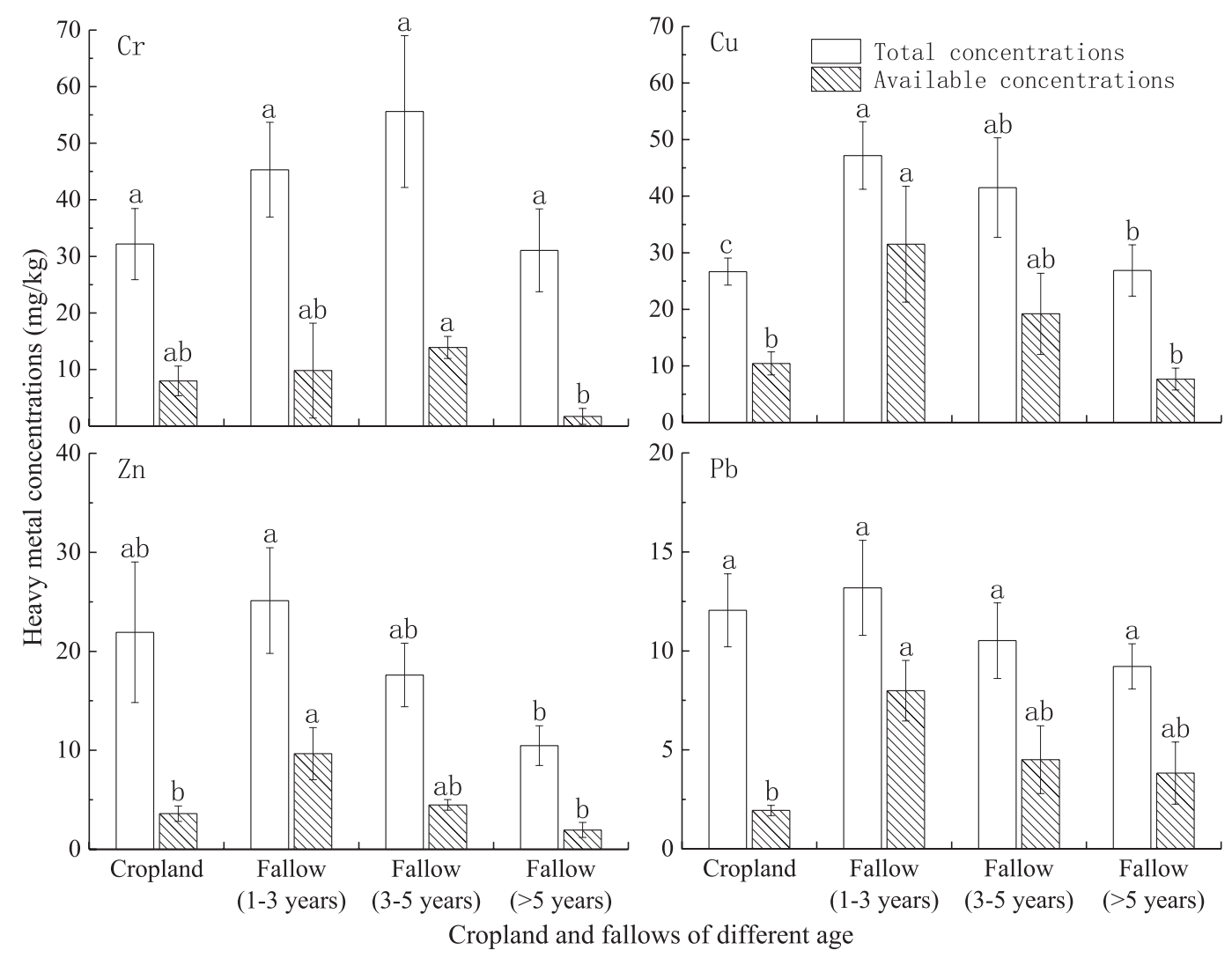

Fig. 2. Total and available concentrations of heavy metals in cropland and fallows of different age. 
Table 2. Correlation coefficient matrix between available concentrations of heavy metals and selected soil physicochemical properties ${ }^{\mathrm{a}}$ in surface soils of the study area.

\begin{tabular}{|c|c|c|c|c|c|c|c|}
\hline Element & $\mathrm{HMs}_{\mathrm{t}}$ & $\mathrm{pH}$ & $\mathrm{Eh}$ & $\mathrm{OM}$ & $\mathrm{D} 10$ & D50 & D90 \\
\hline $\mathrm{Cr}_{\mathrm{a}}$ & $0.795^{* *}$ & -0.568 & 0.554 & 0.428 & -0.094 & 0.002 & 0.048 \\
\hline $\mathrm{Cu}_{\mathrm{a}}$ & $0.736^{* *}$ & $-0.856^{* *}$ & $0.867^{* *}$ & $0.813^{* *}$ & $0.564^{*}$ & $0.724^{* *}$ & $0.761^{* *}$ \\
\hline $\mathrm{Zn}$ & $0.574^{*}$ & $-0.782^{* *}$ & $0.808^{* *}$ & $0.776^{* *}$ & $0.501^{*}$ & $0.606^{* *}$ & $0.549^{*}$ \\
\hline $\mathrm{Pb}_{\mathrm{a}}$ & $0.561^{*}$ & $-0.677^{*}$ & $0.692^{*}$ & $0.697^{*}$ & $0.766^{* *}$ & $0.837^{* *}$ & $0.840^{* *}$ \\
\hline
\end{tabular}

The subscripts " $\mathrm{t}$ " and "a" following heavy metal symbols indicate the total concentrations and available concentrations of heavy metals, respectively. **, * Significant at $\mathrm{P}<0.01$ and $\mathrm{P}<0.05$, respectively.

${ }^{\text {a }} \mathrm{HMs}=$ heavy metals; $\mathrm{Eh}=$ redox potential; $\mathrm{OM}=$ organic matter; D10, D50, D90 $=10^{\text {th }}-50^{\text {th }}-90^{\text {th }}$ percentile of particle diameter curve.

different degrees of biological toxicity [28]. Therefore, the correlation between the total and available heavy metals in soil can help us understand the relationship to each other and to recognize their hazards. The correlation between total and available concentrations of the four heavy metals was analysed. The results are shown in Table 2. The total concentrations of the four elements were positively correlated with the available concentrations. Total $\mathrm{Cr}$ and $\mathrm{Cu}$ showed an extremely significant positive correlation to their available concentrations, and the correlation coefficients were 0.795 and 0.736 , respectively. Total $\mathrm{Zn}$ and $\mathrm{Pb}$ showed a significant positive correlation to their available concentrations, and the correlation coefficients were 0.574 and 0.561 , respectively. It can be seen that soils with high total concentrations of heavy metals also have high available concentrations, so the available and total concentration of heavy metals have a consistent spatial distribution. In addition, the available concentrations of four heavy metals were significantly and positively correlated with the total concentration, indicating that the concentration of available heavy metals was greatly affected by the total heavy metals.

\section{Soil Physicochemical Characteristics}

In addition to the total concentration of heavy metals, the physicochemical properties of soil also affect the available heavy metals. Soil physicochemical properties such as $\mathrm{pH}, \mathrm{Eh}, \mathrm{OM}$ and particulate diameter may affect the available heavy metals. In this paper, the correlations among $\mathrm{pH}$, Eh, OM, particulate diameter and available heavy metals were examined (Table 2), and the effects of soil physicochemical properties on available heavy metals were determined. Soil $\mathrm{pH}$ is an important factor affecting the charge characteristics of heavy metals, such as their precipitation-dissolution, adsorption-desorption, and coordination-dissociation equilibrium [29]. As shown in Table 2, the available concentrations of $\mathrm{Cr}, \mathrm{Cu}, \mathrm{Zn}$ and $\mathrm{Pb}$ were negatively correlated with soil $\mathrm{pH}$. Among these metals, $\mathrm{Cu}, \mathrm{Zn}$ and $\mathrm{Pb}$ have a high correlation coefficient with $\mathrm{pH}$. When the soil $\mathrm{pH}$ decreases, the solubility of heavy metals in the soil solution increases, and the capacity of soil to adsorb heavy metals decreases, so the available concentration of heavy metals increases with a decrease in $\mathrm{pH}$. The soil in the study area was slightly acidic with an average value of 5.96. Heavy metals were prone to migration. The Eh affects the fractions of inorganic and $\mathrm{OM}$ in soil by changing the valence of heavy metal ions, which leads to the migration and transformation of heavy metals. Usually, an increase in Eh will lead to a decrease in $\mathrm{pH}$, which will increase the available concentrations of heavy metals. The Eh of soil samples ranged from 2.2 to $129.40 \mathrm{mV}$, with a mean value of $79.30 \mathrm{mV}$, indicating that the soil in the study area was highly oxidized. The Eh was positively correlated with available concentrations of four heavy metals, of which $\mathrm{Cu}, \mathrm{Zn}, \mathrm{Pb}$ were significantly and positively correlated with Eh, which was consistent with the conclusions of Kelderman and Osman [30]. The available concentrations of $\mathrm{Cu}$, $\mathrm{Zn}$ and $\mathrm{Pb}$ were significantly and positively correlated with OM. This result is because soil OM is mainly composed of biomolecules and humus (mainly humic acid and fulvic acid), which affect the available heavy metals through electrostatic adsorption, complexation and chelation [31]. Fulvic acid is strongly acidic and mobile, which can significantly promote the desorption of heavy metals in polluted soil and improve the available concentration of heavy metals, while the absorption capacity of humic acid is high, it can significantly reduce the dissolution of heavy metals in polluted soil. D10, D50 and D90 of the soil samples ranged from 1.52 to $41.20,13.60$ to 277.00 and 61.10 to $603.00 \mu \mathrm{m}$, respectively. The soil was coarse in texture. $\mathrm{Cu}, \mathrm{Zn}$ and $\mathrm{Pb}$ were significantly and positively correlated with D10, D50 and D90, indicating that the higher the content of fine particles in soil, the lower the concentration of available heavy metals. This observation is because heavy metal ions are preferentially adsorbed and immobilized in soil components with large surface areas and have a strong adsorption capacity for heavy metal ions, e.g., oxides, clay minerals and humus, which are mainly distributed in fine particles. 


\section{Conclusions}

The concentration of available heavy metals differed in 1-3 year fallow, 3-5 year fallow and > 5-year fallow. As fallows aged, the physicochemical properties of fallows changed and $\mathrm{pH}, \mathrm{Eh}, \mathrm{OM}$ and particulate diameter were significantly correlated with available heavy metals. The $\mathrm{pH}$ was negatively correlated with available heavy metals. The Eh, soil OM and particulate diameter were positively correlated with available heavy metals. Therefore, short-term fallow of the soil cannot reduce the concentration of available heavy metals, and it may take a long time ( $>5$ years) to reduce the concentration of available heavy metals. The duration of fallow plays an important role in reducing heavy metals in soil. More appropriate fallow methods and changes in soil properties are of great significance to the protection of cropland.

\section{Acknowledgements}

This study was supported by the Hainan Natural Science Foundation Innovation Team (CN) (2017CXTD006), Geological Survey Project: Data Integration and Comprehensive Analysis of Resources and Environment Geological Survey (CN) (DD20190427), and the Natural Science Foundation of Hainan Province (CN) (419MS049). The authors thank Yan Li and Yaoli Xing for help with sampling.

\section{Conflict of Interest}

No potential conflict of interest was reported by the authors.

\section{References}

1. CASTillo A.M.L., TRUjillo S.I., AlONSO V.E., DE TORRES G.A., PAVON C.J.M. Bioavailability of heavy metals in water and sediments from a typical Mediterranean Bay (Malaga Bay, Region of Andalucia, Southern Spain). Marine Pollution Bulletin, 76, 427, 2013.

2. STAFILOV T., ŠAJN R., AHMETI L. Geochemical characteristics of soil of the city of Skopje, Republic of Macedonia. Journal of Environmental Science and Health, Part A, 10 (54), 972, 2019.

3. SUPERVILLE P.J., PRYGIEL E., MAGNIER A., LESVEN L., GAO Y., BAEYENS W., OUDDANE B., DUMOULIN D., BILLON G. Daily variations of $\mathrm{Zn}$ and $\mathrm{Pb}$ concentrations in the Deûle River in relation to the resuspension of heavily polluted sediments. Science of Total Environment, 470-471, 600, 2014.

4. KELEPERTZIS E., STATHOPOULOU E. Availability of geogenic heavy metals in soils of Thiva town (central Greece). Environmental Monitoring and Assessment, 185, 9603, 2013.

5. LIU C., CUI J., JIANG G.F., CHEN X.F., WANG L., FANG C.M. Soil heavy metal pollution assessment near the largest landfill of China. Soil and Sediment Contamination: An International Journal, 22, 390, 2013.

6. VARDHAN K.H., KUMAR P.S., PANDA R.C. A review on heavy metal pollution, toxicity and remedial measures: Current trends and future perspectives. Journal of Molecular Liquids, 290, 111197, 2019.

7. ZHAO K.L., LIU X.M., XU J.M., SELIM H.M. Heavy metal contaminations in a soil-rice system: identification of spatial dependence in relation to soil properties of paddy fields. Journal of Hazardous Materials, 181, 778, 2010.

8. ZENG F.R., ALI S., ZHANG H.T., OUYANG Y.N., QIU B.Y., WU F.B., ZHANG G.P. The influence of $\mathrm{pH}$ and organic matter content in paddy soil on heavy metal availability and their uptake by rice plants. Environmental Pollution, 159, 84, 2011.

9. MONTERROSO C., RODRÍGUEZ F., CHAVES R., DIEZ J., BECERRA-CASTRO C., KIDD P.S., MACÍAS F. Heavy metal distribution in mine-soils and plants growing in a $\mathrm{Pb} / \mathrm{Zn}$-mining area in NW Spain. Applied Geochemistry, 44, 3, 2014.

10. PEIJNENBURG W.J.G.M., ZABLOTSKAJA M., VIJVER M.G. Monitoring metals in terrestrial environments within a bioavailability framework and a focus on soil extraction. Ecotoxicology and Environmental Safety, 67, 163, 2007.

11. SIMPSON S.L., WARD D., STROM D., JOLLEY D.F. Oxidation of acid-volatile sulfide in surface sediments increases the release and toxicity of copper to the benthic amphipod Melita plumulosa. Chemosphere, 88, 953, 2012.

12. YANG Z.J., JING F., CHEN X.M., LIU W., GUO B.L., LIN G.Z., HUANG R.H., LIU W.X. Spatial distribution and sources of seven available heavy metals in the paddy soil of red region in Hunan Province of China. Environmental Monitoring and Assessment, 190, 611, 2018.

13. XIAN Y., WANG M.E., CHEN W.P. Quantitative assessment on soil enzyme activities of heavy metal contaminated soils with various soil properties. Chemosphere, 139, 604, 2015.

14. FARSHADIRAD A., HOSSEINPUR A., MOTAGHIAN H. Distribution and availability of copper in aggregate size fractions of some calcareous soils. Journal of Soils Sediments, 19, 1866, 2019.

15. POZNANOVIĆ SPAHIĆ M.M., SAKAN S.M., GLAVAŠ-TRBIĆ B.M., TANČIĆ P.I., ŠKRIVANJ S.B., KOVAČEVIĆ J.R., MANOJLOVIĆ D.D. Natural and anthropogenic sources of chromium, nickel and cobalt in soils impacted by agricultural and industrial activity (Vojvodina, Serbia). Journal of Environmental Science and Health, Part A, 3 (54), 219, 2019.

16. RODRÍGUEZ-BOCANEGRA J., ROCA N., FEBRERO A., BORT J. Assessment of heavy metal tolerance in two plant species growing in experimental disturbed polluted urban soil. Journal of Soils and Sediments, 18, 2305, 2018.

17. GALLO A., ZANNONI D., VALOTTO G., NADIMIGOKI M., BINI C. Concentrations of potentially toxic elements and soil environmental quality evaluation of a typical Prosecco vineyard of the Veneto region (NE Italy). Journal of Soils and Sediments, 18, 3280, 2018.

18. INYANG E.P., OKETAYO O.O., OBIAJUNWA E.I. Proton induced X-ray emission analysis of soils with various length of fallow: The effect on soil total elemental composition. Soil \& Tillage Research, 124, 178, 2012.

19. FU B., LIU Y.Y., ZHAO Z.Z., ZHANG L., WU D., LIU H.F. Dissolved palladium in heavy traffic location runoff: dynamic variation and influencing factors. Urban Water Journal, 15, 880, 2018. 
20. NORVELL W.A., LINDSAY W.L. Reactions of DTPA chelates of iron, zinc, copper, and manganese with soils. Soil Science Society of America Journal, 36, 778, 1972.

21. BANI A., ECHEVARRIA G., MONTARGĖS-PELLETIER E., GJOKA F., SULÇE S., MOREL J.L. Pedogenesis and nickel biogeochemistry in a typical Albanian ultramafic toposequence. Environmental Monitoring \& Assessment, 186, 4431, 2014.

22. SEO B.H., KIM H.S., KWON S.I., OVENS G., KIM K.R. Heavy metal accumulation and mobility in a soil profile depend on the organic waste type applied. Journal of Soils and Sediments, 19, 822, 2019.

23. YU Y.C., YANG J.Y., ZENG S.C., WU D.M., JACOBS D.F., SLOAN J.L. Soil pH, organic matter, and nutrient content change with the continuous cropping of Cunninghamia lanceolata plantations in South China. Journal of Soils and Sediments, 17, 2230, 2015.

24. MURRAY M.R. Is laser particle size determination possible for carbonate-rich lake sediments? Journal of Paleolimnology, 27, 173, 2002.

25. GIMENO-GARCÍA E., ANDREU V., BOLUDA R. Heavy metals incidence in the application of inorganic fertilizers and pesticides to rice farming soils. Environmental Pollution, 92 (1), 19, 1996.

26. YU Z.N., TAN Y.Z., WU C.F., MAO M.Z., ZHANG X.L. Alternatives or status quo? Improving fallow compensation policy in heavy metal polluted regions in Chaling County, China. Journal of Cleaner Production, 210, 287, 2019.

27. TANG W.G., XIAO X.P., TANG H.M., ZHANG H.L., CHEN F., CHEN Z.D., XUE J.F., YANG G.L. Effects of long-term tillage and rice straw returning on soil nutrient pools and $\mathrm{Cd}$ concentration. Chinese Journal of Applied Ecology, 26 (1), 168, 2015

28. GASPARATOS D., MAVROMATI G., KOTSOVILIS P., MASSAS I. Fractionation of heavy metals and evaluation of the environmental risk for the alkaline soils of the Thriassio plain: a residential, agricultural, and industrial area in Greece. Environmental Earth Sciences, 74, 1099, 2015.

29. APPEL C., MA L. Concentration, $\mathrm{pH}$, and surface charge effects on cadmium and lead sorption in three tropical soils. Journal of Environmental Quality, 31 (2), 581, 2002.

30. KELDERMAN P., OSMAN A.A. Effect of redox potential on heavy metal binding forms in polluted canal sediments in Delft (The Netherlands). Water Research, 41 (18), 4251, 2007.

31. LU A.X., ZHANG S.Z., SHAN X.Q. Time effect on the fractionation of heavy metals in soils. Geoderma, 125, $225,2005$. 